\title{
Fetal Triploidy Syndrome: a case report from Global Reference Laboratory, Mumbai, India
}

\author{
Shailesh Pande ${ }^{1 *}$, Nitin Choubal ${ }^{2}$, Ashish Parulekar ${ }^{3}$, Anurita Pais ${ }^{1}$, Pratiksha Chheda ${ }^{4}$, \\ Yogita Salunkhe ${ }^{4}$, Sunmeet Matkar ${ }^{4}$
}

\begin{abstract}
${ }^{1}$ Department of Genetics, Metropolis Healthcare Ltd, Unit 409-416, Kurla (W), Mumbai, Maharashtra, India
${ }^{2}$ Department of Radiology, Thane Ultrasound Centre, Shanti Niwas, Dr. Moose Road, Talaopali, Thane (W), Maharashtra, India

${ }^{3}$ Department of Gynecology, Ushah Kal, Hindu Friends Society, Jogeshwari (E), Mumbai, Maharashtra, India

${ }^{4}$ Department of Research and Development, Metropolis Healthcare Ltd, Unit 409-416, Kurla (W), Mumbai, Maharashtra, India
\end{abstract}

Received: 17 March 2017

Accepted: 21 April 2017

\section{*Correspondence:}

Dr. Shailesh Pande,

E-mail: shailesh.pande@metropolisindia.com

Copyright: () the author(s), publisher and licensee Medip Academy. This is an open-access article distributed under the terms of the Creative Commons Attribution Non-Commercial License, which permits unrestricted non-commercial use, distribution, and reproduction in any medium, provided the original work is properly cited.

\begin{abstract}
Triploidy is a complete extra set of chromosomes. In the current case report, we present the case of a 29-year-old pregnant female who was referred to Department of Genetics, Metropolis Healthcare Ltd, Mumbai. Real-time sonography of the gravid uterus was done using a 3C RS multi-frequency probe. Placenta was observed to be posterior. The findings were suggestive of a single viable foetus with an average gestational age of 14.6 weeks at $14-$ 15 weeks of pregnancy and only mild placental thickening at 17-18 weeks of pregnancy was detected on Ultrasound at the time of Amniocentesis. The fetal chromosomal study on amniotic fluid by Fluoroscence insitu hybridization (FISH) revealed trisomy status for chromosome 13, 18, 21, X and Y in 100\% of the cells analysed and the fetal karyotype revealed a presence of extra set of chromosomes (69) in all the analysed cells. Parental blood karyotype was done for checking cytogenetic abnormality or variations. FISH studies with POC specimen revealed Trisomy status for chromosomes 13, 18, 21 and presence of extra Sex chromosome (XXY) in all cells analysed.
\end{abstract}

Keywords: Fluoroscence insitu hybridization (FISH), Karyotype, Triploidy

\section{INTRODUCTION}

Triploidy is a complete extra set of chromosomes and results in a clinically recognizable lethal syndrome with hydatiform placental changes, severe intrauterine growth deficiency, cranial bone abnormalities, eye defects, malformed ears, syndactyly, genital anomalies, congenital heart defects and brain anomalies. ${ }^{1}$ It is a rare syndrome and is estimated to occur in about 2 per cent of conceptuses. $^{2}$ The identification of the syndrome is of utmost importance as most of them die within the first 2 months, and also for the family for further genetic counselling, planning for future family and for their grieving. As we know very few cases with fetal triploidy sustain above 12 weeks we report a case to highlight the pregnancy that sustained up to 19 weeks. The fetal tripoidy was detected in Amniotic fluid fetal karyotype.

\section{CASE REPORT}

In this report, we present the case of a 29-year-old pregnant female who was referred to Department of Genetics, Global Reference Laboratory, Metropolis 
Healthcare Ltd, Mumbai. The personal medical history of this patient was unremarkable. She had a history of Abortion. Real-time sonography of the gravid uterus was done using a 3C RS multi-frequency probe. Fetal weight was recorded at 104 grams. Placenta was observed to be posterior. Nuchal thickness was measured at around $1.5 \mathrm{~mm}$. Nasal bone was recorded as normal. The findings were suggestive of a single viable foetus with an average gestational age of 14.6 weeks at 14-15 weeks of pregnancy and only mild placental thickening at 17-18 weeks of pregnancy was detected on Ultrasound at the time of Amniocentesis. The reason for amniocentesis and fetal chromosomal karyotyping was an inconclusive Quadruple marker test. The fetal chromosomal study on amniotic fluid by Fluoroscence insitu hybridization (FISH) revealed trisomy status for chromosome 13, 18, $21, \mathrm{X}$ and $\mathrm{Y}$ in $100 \%$ of the cells analysed and the fetal karyotype revealed a presence of extra set of chromosomes (69) in all the analysed cells. Hence the case was reported by our Medical Geneticist as Triploidy syndrome. The patient was also recommended for Genetic Counselling and aslo parental blood karyotype was done to see any cytogenetic abnormality or variations. Husband's karyotype showed 44, XY that is apparently normal karyotype while wife had shown 44, $\mathrm{XX} ; 15 \mathrm{ps}+$ (Slightly increase in the length of satellite on one of the chromosome 15). Meanwhile at 19-19.5 weeks the patient had a miscarriage and after Medical Termination of Pregnancy (MTP) for academic purpose the Abortus material (POC) sample was asked for Cytogenetic (FISH) and Histopathology studies. FISH studies with POC specimen revealed Trisomy status for chromosomes 13, 18, 21 and presence of extra Sex chromosome (XXY) in all cells analysed.

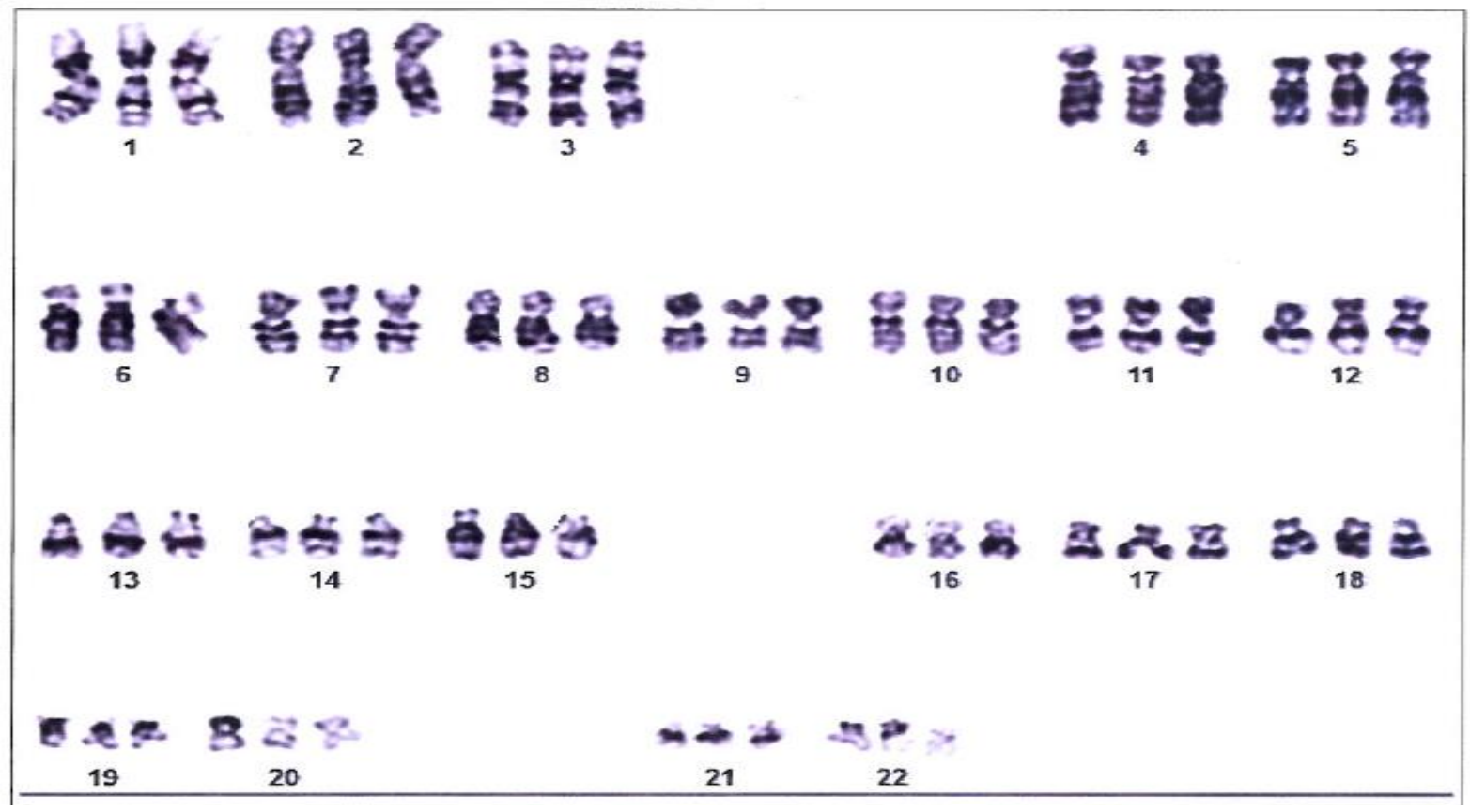

Figure 1: Amniotic cell culture metaphase karyotype: ' $G$ ' banding.

Table 1: Analysis of STR Markers using amniotic fluid.

\begin{tabular}{|c|c|c|c|c|c|}
\hline Amelogenin & $\begin{array}{l}\text { Position on } \\
\text { Chromosome }\end{array}$ & $\begin{array}{l}\text { Amniotic Fluid of } \\
\text { Mother - Genotype }\end{array}$ & $\begin{array}{l}\text { Mother } \\
\text { Genotype }\end{array}$ & Father Genotype & $\begin{array}{l}\text { Ratio Amniotic } \\
\text { Genotype: Father: Mother }\end{array}$ \\
\hline CSF1PO & $5 q 33.1$ & $11,12,13$ & 10,12 & 11,13 & $1: 1: 1$ \\
\hline D16S539 & $16 q 24.1$ & $9,10,11$ & 10,12 & 9,11 & $1: 1: 1$ \\
\hline D18S51 & $18 \mathrm{q} 21.33$ & $12,14,17$ & 12,16 & 14,17 & $1: 1: 1$ \\
\hline D19S433 & $19 q 12-13.1$ & 14,15 & $14,14.2$ & 14,15 & $2: 1$ \\
\hline D21S11 & $21 \mathrm{q} 21.1$ & $29,31.2$ & 28,29 & $30.2,31.2$ & $1: 2$ \\
\hline D2S1338 & $2 q 35-37.1$ & 19,24 & 23,24 & 19,22 & $2: 1$ \\
\hline D5S818 & $5 q 23.2$ & $10,11,13$ & 13,14 & 10,11 & 1:1:1 \\
\hline D7S820 & $7 \mathrm{q} 21.11$ & 8,11 & 8,10 & 8,11 & $2: 1$ \\
\hline D8S1179 & $8 \mathrm{q} 24.13$ & 10,11 & 10,11 & 10,15 & $2: 1$ \\
\hline FGA & $4 \mathrm{q} 31.3$ & $19,23,25$ & 23,25 & 19,25 & 1:1:1 \\
\hline TH01 & $11 \mathrm{p} 15.5$ & $9,9.3$ & $9.3,9.3$ & 8,9 & $2: 1$ \\
\hline TPOX & $2 \mathrm{p} 25.3$ & $8,11,12$ & 8,11 & 11,12 & 1:1:1 \\
\hline vWA & $12 \mathrm{p} 13.31$ & $17,18,19$ & 19,19 & 17,18 & $1: 1: 1$ \\
\hline
\end{tabular}




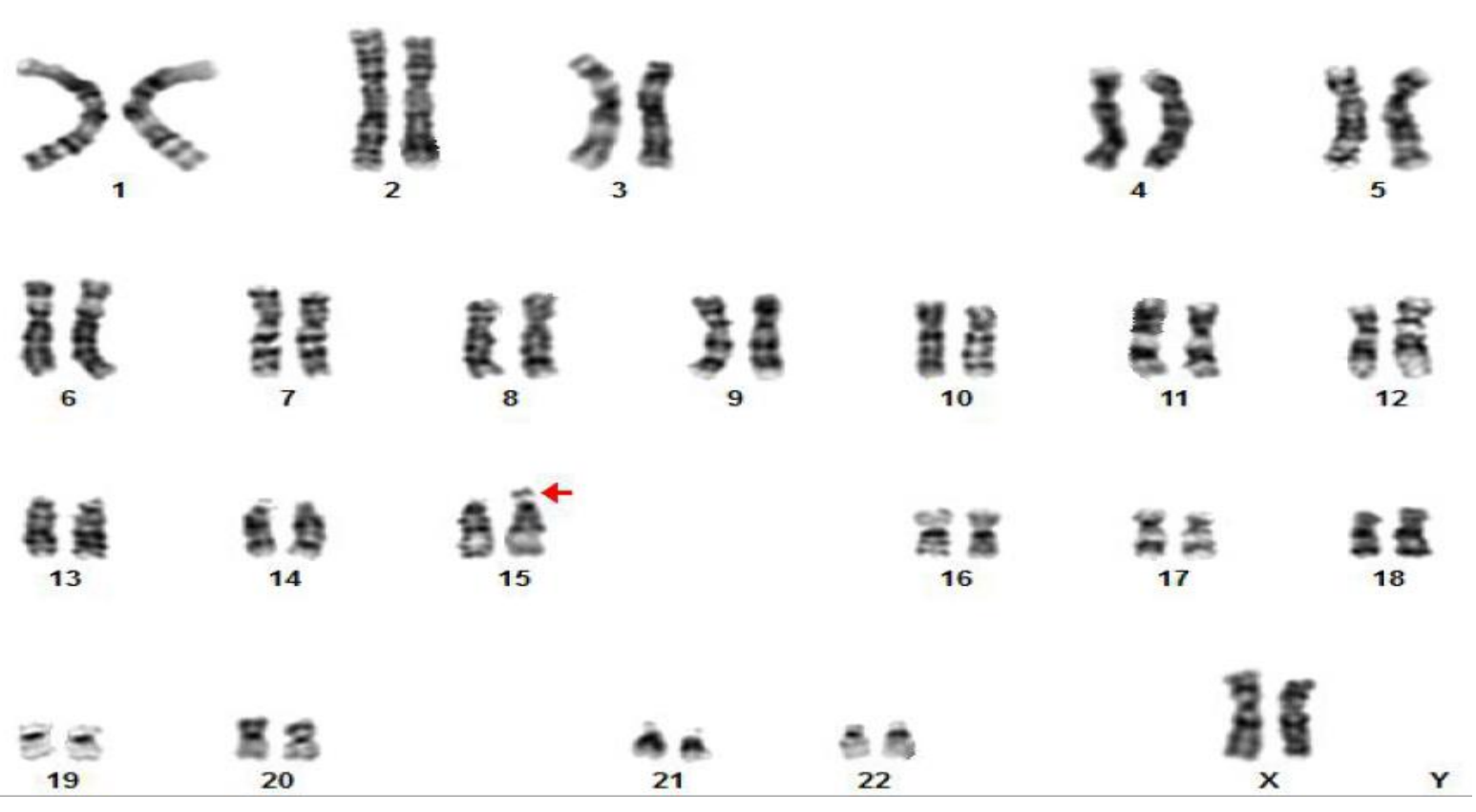

Figure 2: Report of karyotype analysis.

Histopathological studies noted grape like vesicles after gross examination suggestive of Molar pregnancy. No evidence of malignancy was recorded. Further, to ascertain the mode of transmission of the extra set of chromosomes either maternal (digyny) or paternal (diandry), molecular studies on amniotic fluid were done. Analysis of STR Marker Using AmpFISTR Identifiler Plus Kit revealed triploidy in the amniotic fluid specimen. Comparison of similar STR profiles in Mother and Father Specimen revealed this triploidy to be diandric.

\section{DISCUSSION}

Triploidy syndrome is characterized by general dysmaturity, muscular hypotonia, large posterior fontanel, low set dysmorphic auricles, hypertelorism, microphthalmia and colobomata, cutaneous syndactaly of third and fourth fingers, simian crease, hypospadias and/or mal-developed external genitalia. ${ }^{3}$

Triploidy is not uncommon in early pregnancy (1\% - 3\% of recognized conceptions), but about $99.99 \%$ are lost as first-trimester miscarriage or second-trimester fetal death in utero. ${ }^{4}$ Studies carried out by Forrester and Merz reveal that out of 38 recognized triploid pregnancies in their 14-year long study period, around $40 \%$ were XXX, $60 \% \mathrm{XXY}$, and a single case of XYY.

Most (80\%) aborted early, a few (10\%) presented as fetal deaths in utero and $10 \%$ were electively terminated. ${ }^{5}$ Diandric triploids mostly abort in the 10 - to 20 -week period, the mean at 12 weeks. The very few diandric triploid pregnancies that survive to the second trimester typically show partial hydatiform mole; growth retardation is usual but not invariable. ${ }^{4}$ Dygynic triploids mostly abort early (mean 10 weeks), although those exceptional few that remain are able to continue through to the third trimester, when they come to outnumber diandric cases. These surviving digynic triploids develop as a severely growth related fetus with marked head-body disproportion, the head being relatively large, and with an abnormally small and non-molar placenta. ${ }^{6}$ Survival to the third trimester is associated almost invariably with perianal death. Of those live born, hardly any digynic triploids survive for more than a month. ${ }^{7}$

All the reports were discussed with the referring doctor and the case was treated accordingly for molar pregnancy and thus the patient was benefited.

Funding: No funding sources

Conflict of interest: None declared

Ethical approval: Not required

\section{REFERENCES}

1. Witters G, Van Robays J, Willekes C, Coumans A, Peeters H, Gyselaers W, et al. Trisomy 13, 18, 21, Triploidy and Turner syndrome: the 5T's. Look at the hands. Facts, views and vision in ObGyn. 2011;3(1):15.

2. Kumar RK, Negi SP. Triploidy Syndrome. Indian Pediatr. 2000;37(2):201-3.

3. Garg A, Prabha R, Garg A, Kumar S. Fetal Triploidy Syndrome. A Case Report. J Med Sci Clini Res. 2016;4(11):13940-2.

4. McKinlay GRJ, Grant R. Sutherland. Chromosome Abnormalities and Genetic Counseling. Oxford 
Monographs on Medical Genetics. $4^{\text {th }}$ Ed. New York, NY: Oxford University Press; 2012:288-289.

5. Forrester M, Merz R. Epidemiology of triploidy in a population-based birth defects registry, Hawaii, 1986-1999. Am J Med Genetics. 2003;119A(3):319:23.

6. McFadden DE, Langlois S. Parental and meiotic origin of triploidy in the embryonic and fetal periods. Clinical Genetics. 2000;58:192-200.
7. Hasegawa T, Harada N, Ikeda K, Ishii T, Hokuto I, Kasai K, et al. Digynic triploid infant surviving for 46 days. Am J Med Genetics. 1999;87(4):306-10.

Cite this article as: Pande $\mathrm{S}$, Choubal N, Parulekar A, Pais A, Chheda P, Salunkhe Y, et al. Fetal Triploidy Syndrome: a case report from Global Reference Laboratory, Mumbai, India. Int J Reprod Contracept Obstet Gynecol 2017;6:2631-4. 